\title{
A Case Of Placental Chorioangioma With The Review Of Literature
}

\author{
S Acharya, S Pringle
}

\section{Citation}

S Acharya, S Pringle. A Case Of Placental Chorioangioma With The Review Of Literature. The Internet Journal of Gynecology and Obstetrics. 2004 Volume 5 Number 1.

\section{Abstract}

Chorioangioma of the placenta is a relatively rare problem which most often goes unnoticed. However, it has potentially serious fetal risks and so the pregnancy needs to have regular surveillance. There has been a host of interventions described in the literature when complications develop. The larger the size of the tumor the more is the chance of developing complications. We present a case with large chorioangioma without any serious complications and a successful outcome.

\section{CASE REPORT}

A 28 year old primigravida was booked at 14 weeks of pregnancy. Her triple test showed her to be low risk with normal levels of the hormones alpha fetoprotein and $\mathrm{\square}$-hCG. She then travelled to Pakistan where she underwent a scan which showed a $17+2$ weeks single viable pregnancy and a small hypo echoic area $3 \times 2 \mathrm{cms}$ near the lower edge of the placenta. Colour Doppler performed showed prominent vasculature suggestive of chorioangioma. She had regular antenatal check up in Pakistan and the pregnancy was uneventful. She was again seen at our hospital in the UK at 38 weeks of pregnancy when a scan showed normally growing fetus with normal liquor volume but a $10.3 \times 10.7 \times 8.9 \mathrm{cms}$ hypoechoic area in the placenta (Figure: I).

\section{Figure 1}

Figure 1

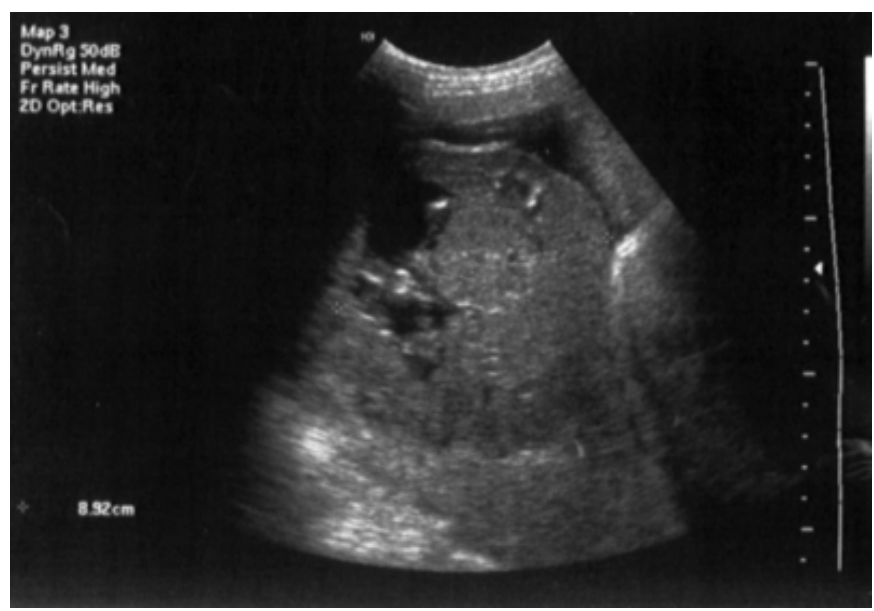

Doppler studies revealed normal diastolic flow. She was induced at 39 weeks and had a straight forward normal delivery of a female baby with normal Apgar score and birth weight of 2.82 kilograms. Placenta was delivered by controlled cord traction and sent for histopathology. Macroscopically, the placenta was $18 \times 16 \times 6.5 \mathrm{cms}$ and weighed 1060 grams. There was a large polypoid lesion on the placenta measuring $12 \times 12 \times 8.5 \mathrm{cms}$ ( Figure: II).

\section{Figure 2}

Figure 2

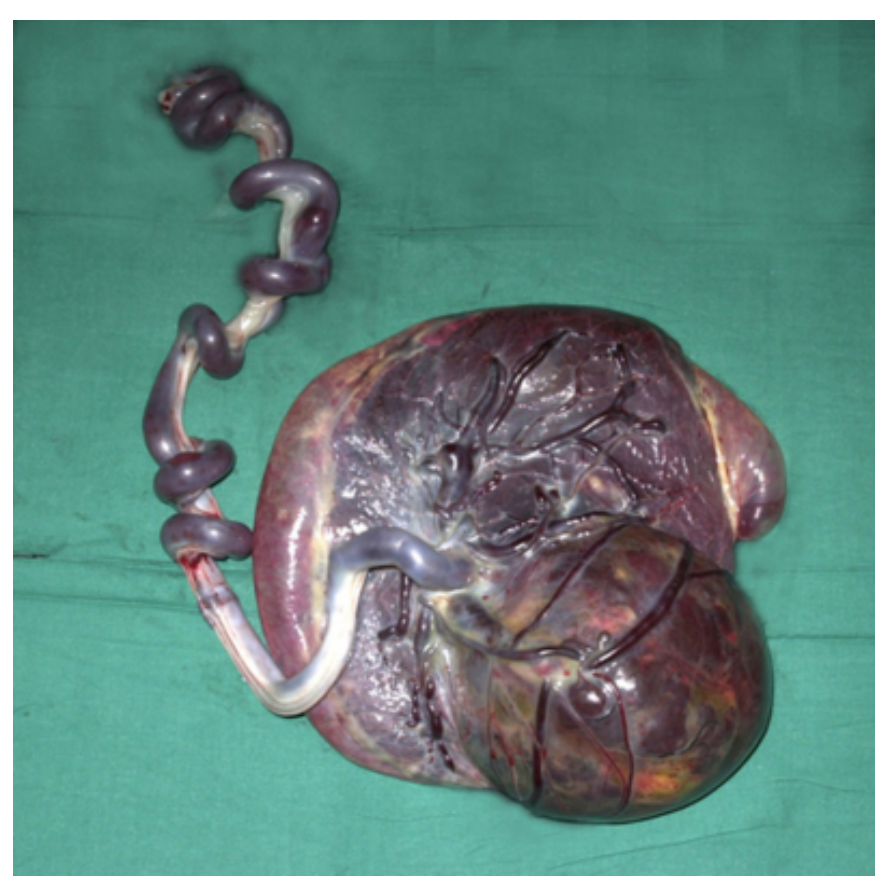

On sectioning this consisted of multiple dialated vascular channels. Histology confirmed plurinodal chorioangioma. 
Both the mother and the baby were discharged in good condition following delivery.

\section{DISCUSSION WITH REVIEW OF LITERATURE}

Chorioangioma of the placenta is a benign vascular tumour arising from the primitive chorionic mesenchyme whose etiology is unknown. Incidence of large chorioangioma ( $>4$ cms) varies from 1:3500 to 1:9000 $\left(_{1}\right)$. One of the largest retrospective studies on 22439 unselected placentas found 136 chorioangiomas with an incidence of $0.61 \%\left({ }_{2}\right)$. They were associated with increased maternal age, diabetes mellitus and hypertension. They are more common in multiple pregnancy and female babies.

Most cases of chorioangioma are diagnosed following delivery. However, increased alpha-fetoprotein $\left({ }_{3},{ }_{4}\right)$ or $\square$ hCG ${ }_{5}$ ) can arouse suspicion. Ultrasound is the mainstay in diagnosing chorioangioma although there is no specific finding which is diagnostic. Colour Doppler imaging not only helps differentiate chorioangioma from other lesions like degenerating fibroid, placental teratoma, deceased twin, placental haematoma but also is useful in the prenatal follow-up of these cases $\left({ }_{6}\right)$.

The main fetal risks include non immune hydrops fetalis, cardiomegaly, congestive cardiac failure, anaemia, thrombocytopenia, consumptive coagulopathy, prematurity and sudden infant death $(7,8,9)$. Maternal risks are mainly polyhydramnios and preterm delivery $\left({ }_{10}\right)$.

Various interventions have been tried to prevent or treat complications of chorioangioma with varying success. Prenatal treatment by ultrasound guided interstitial laser therapy $\left({ }_{11}\right)$, in-utero endoscopic devascularization with use of suture ligation or bipolar cautery via fetoscopy $\left({ }_{1}\right)$, microcoil embolisation $\left(_{12}\right)$ and alcohol injection $\left(_{13}\right)$ have been described in the literature. In case of severe fetal anaemia, diagnosed best by colour flow Doppler of the middle cerebral artery, fetal blood sampling and intrauterine transfusion may be beneficial to preserve fetal health until maturity is reached $\left({ }_{14}\right)$. Polyhydramnios has been treated by therapeutic amniodrainage $\left({ }_{15}\right)$ and indomethacin therapy $\left({ }_{16}\right)$.

In our case the chorioangioma has been detected by scan in early pregnancy but all biochemical markers were normal. The pregnancy was uneventful in spite of such a large chorioangioma and led to a successful outcome with conservative management.

\section{CONCLUSION}

Large chorioangiomas are rare and it is not necessary that complications would always ensue. There is a place for conservative management with successful outcome as has been described in the literature $\left({ }_{17}\right)$. However, regular monitoring by serial ultrasound, doppler waveform surveillance and fetal echocardiography is recommended to pick up complications early so that they can be dealt with effectively.

\section{References}

1. Quintero RA, Reich H, Romero R, Johnson MP, Gonhalves L, Evans MI: In utero endoscopic devascularization of a large chorioangioma. Ultrasound Obstet Gynecol 1996; 8: 48-52

2. Guschmann M, Henrich W, Entezami M, Dudenhausen JW: Chorioangioma-new insights into a well-known problem. I. Results of a clinical and morphological study of 136 cases. J Perinat Med. 2003;31(2):163-9.

3. Khong TY, George K: Maternal serum alpha-fetoprotein levels in chorioangiomas. Am J Perinatol 1994; 11: 245-8

4. Johnson VP: Rare causes of elevated maternal serum alpha-fetoprotein. A report of three cases. J Reprod Med. 1992 Jan;37(1):93-6

5. Bashiri A, Maymon E, Wiznitzer A, Maor E, Mazor M: Chorioangioma of the placenta in association with early severe polyhydramnios and elevated maternal serum HCG: a case report. Eur J Obstet Gynecol Reprod Biol. 1998 Jul;79(1):103-5.

6. Zalel Y, Gamzu R, Weiss Y, Schiff E, Shalmon B, Dolizky M, Achiron R: Role of color Doppler imaging in diagnosing and managing pregnancies complicated by placental chorioangioma. J Clin Ultrasound. 2002 Jun;30(5):264-9.

7. Demiriz M, Tunca Y, Ozcan A, Celasun B, Finci R. Placental chorioangioma associated with fetal cardiac complication. Acta Obstet Gynecol Scand. 1997

Aug;76(7):708-9

8. Zoppini C, Acaia B, Lucci G, Pugni L, Tassis B, Nicolini U. Varying clinical course of large placental chorioangiomas. Report of 3 cases. Fetal Diagn Ther. 1997 Jan-Feb;12(1):61-4

9. Batukan C, Holzgreve W, Danzer E, Bruder E, Hosli I, Tercanli S. Large placental chorioangioma as a cause of sudden intrauterine fetal death. A case report. Fetal Diagn Ther. 2001 Nov-Dec;16(6):394-7.

10. Bashiri A, Furman B, Erez O, Wiznitzer A, Holcberg G, Mazor M. Twelve cases of placental chorioangioma.

Pregnancy outcome and clinical significance. Arch Gynecol Obstet. 2002 Jan;266(1):53-5

11. Bhide A, Prefumo F, Sairam S, Carvalho J,

Thilaganathan B. Ultrasound-guided interstitial laser therapy for the treatment of placental chorioangioma. Obstet Gynecol. 2003 Nov;102(5 Pt 2):1189-91.

12. Lau TK, Leung TY, Yu SC, To KF, Leung TN. Prenatal treatment of chorioangioma by microcoil embolisation.

BJOG. 2003 Jan;110(1):70-3.

13. Nicolini U, Zuliani G, Caravelli E, Fogliani R, Poblete

A, Roberts A. Alcohol injection: a new method of treating placental chorioangiomas. Lancet. 1999 May 15;353(9165):1674-5

14. Haak MC, Oosterhof H, Mouw RJ, Oepkes D,

Vandenbussche FP. Pathophysiology and treatment of fetal anemia due to placental chorioangioma. Ultrasound Obstet 
Gynecol. 1999 Jul;14(1):68-70.

15. As AK, Hagen P, Webb JB, Wijesinghe D. therapeutic amniodrainage in chorioangioma. J Obstet Gynaecol. 1997; 17(2):169-170.

16. Kriplani A, Abbi M, Banerjee N, Roy KK, Takkar D.
Indomethacin therapy in the treatment of polyhydramnios due to placental chorioangioma. J Obstet Gynaecol Res. 2001 Oct;27(5):245-8

17. Esen UI, Orife SU, Pollard K. Placental chorioangioma: a case report and literature review. Br J Clin Pract. 1997 Apr-May;51(3):181-2. 


\section{Author Information}

Santanu Acharya, MD, MRCOG

Specialist Registrar, Department of Obstetrics and Gynaecology, Airedale General Hospital

\section{Stewart Pringle, MRCGP, MRCOG}

Clinical Director, Consultant Obstetrician and Gynaecologist, Department of Obstetrics and Gynaecology, Southern General Hospital 